\title{
Design and Implementation of a Chatbot for Kurdish Language Speakers Using Chatfuel Platform
}

\author{
Hemn Mela Karim Barznji \\ Information Technology \\ Computer Science Institute \\ Sulaimani Polytechnic University \\ Sulaimani, Iraq \\ dr.hemn@yahoo.com
}

\author{
Jamal Ali Hussein \\ Computer Department \\ College of Science \\ University of Sulaimani \\ Sulaimani, Iraq \\ jamal.ali@univsul.edu.io
}

\begin{tabular}{l} 
Article Info \\
Volume 5 - Issue 2 - \\
December 2020 \\
DOI: \\
10.24017/science.2020.2.10 \\
Article history: \\
Received : 22 Sept 2020 \\
Accepted: 30 December 2020 \\
\hline
\end{tabular}

Keywords:

Chatbot, Kurdish Language, NLP, Software Robotic, Artificial Intelligent, Kurd Agent.

\begin{abstract}
Chatbot is a software agent that is used to conduct intelligent conversations between machines and humans. Chatbots are mostly depend on Natural Language Processing (NLP). In this paper, the design and implementation of a chatbot are provided to help Kurdish speakers in using online conversations via texts to find answers instead of direct contact with human agents. The NLP-based software agent is implemented using the Chatfuel platform. Chatfuel uses artificial intelligence to communicate with humans by simulating human conversations through voice commands or texts. The proposed chatbot is tested on an electronic tourist guide that helps visitors to the religious places in the mountainous village of Barzanja that is located in Iraqi Kurdistan. The case study is conducted by using threehundred questions and answers. One hundred volunteers participated in this study. The participant asks a question and the bot provides an answer if it recognizes the question, otherwise it provides a default answer along with a suggestion of how to use the system properly. The data of these experiment is collected, analyzed, and problems regarding Kurdish language are detected. Designing software agents for processing Kurdish texts faces many challenges. Kurdish texts have not yet been processed using natural language processing (NLP). In addition, Kurdish font disorder and the lack of standardized keyboards and writing styles makes processing Kurdish text difficult. Furthermore, Kurdish language consists of variety of different dialects with different typing styles. In this research, we specifically focus on the design of a software agent for the Central Kurdish (Sorani) dialect. We managed to solve some of the problems related to the Kurdish language and suggest solutions to others.
\end{abstract}

Copyright ( 2020 Kurdistan Journal of Applied Research. 
All rights reserved.

\section{INTRODUCTION}

Chatbot is a software agent that is used to conduct friendly intelligent conversation between a machine and human. The chatbot term refers to text conversation, but now growing through other communication means such as voice. Enhanced chatbots can also reply using images, relational links, gallery, video, etc. [1]. The basic conceptual and objective of chatbot creation is that the computer talks in natural language with human in reality, which should be as human as possible. Based on this, the chatbot is built for conversations and usually offers a special idea such as searching the Internet, organizing files on a computer, arranging engagement and appointments, and so on [2].

There are numerous chatbot applications for helping users in finding flights, hotels, travel destinations, and jobs. Chatbot is used in many areas, such as ecommerce, banking, entertainment, health, and Education [3]. Chatbots have many advantages over direct conversations, such as availability, reduced costs, and the enhancement of social experiences. There are many software applications available to create chatbot agents. These applications are simple to implement because they allow users to create chatbots without writing any code, but they also enable professional developers to write codes if necessary. Common examples of AI chatbot platforms are: Chatfuel, Bot Framework, Wit.ai, Manychat, Dialogflow, etc.

We have worked with the chatfuel platform since it is one of the best chatbot engines that uses artificial intelligence (AI) to communicate with human. It simulates human conversation through voice commands or text conversations or both. The focus is on automation and adaptability, from answering questions to collecting data [4]. We use this powerful chatbot builder to create a chatbot as a tourist guide for Barzanja ${ }^{1}$ village. Although we focus on Central Kurdish (Sorani) dialect speakers using Kurdish alphabet, which a common writing style in Iraqi Kurdistan, but the proposed chatbot system is capable of enhancing its response whenever a new word or question is entered by the users even if they use different dialect or writing styles. A case study that consists of three-hundred questions and answers and one hundred participants is conducted.

When we applied this research, some challenges have occurred, such as Kurdish Font disorder, different typing styles, punctuations and non-standardized Kurdish language. We provide solutions to some of the problems related to using Kurdish language in NLP systems and provide suggestion to some other problems.

\subsection{Challenge and Problems}

The following challenges and problems are related to NLP of the Kurdish language:

1- Writing Styles Variation: Kurdish language has several formal writing styles with some unformal styles such as Latin style, English alphabet, Central Kurdish style (Sorani) and Arabic alphabet. For examples, the following words have the same meaning ('Come' in English) but have been written using either different words or the same word with different writing styles:

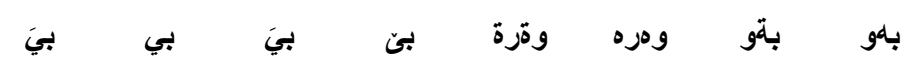

2- Dialectal Variation: Kurdish language has different dialects according the area of Kurdistan. Each dialect has its own grammar and vocabulary. Mixing these dialects is problematic when using Kurdish text in NLP based systems such as chatbots.

3- Orthographic Ambiguity and Inconsistency: In Kurdish language; vocabulary, grammar and writing styles sometime cause ambiguity and inconsistency that are difficult to determine and classify.

\footnotetext{
${ }^{1}$ A thirteenth century village located in a mountainous area near the city of Sulaimani (Sulaymaniyah) in Iraqi Kurdistan. It is a place for many Islamic and Yarsani shrines and holy sites.
} 
4- Morphological Richness: Kurdish words are inflected for a several of features, such as gender, number, person, voices, aspect, etc., that have different formats according to the dialect. For example, the following pair of words have close spellings with totally different meanings:

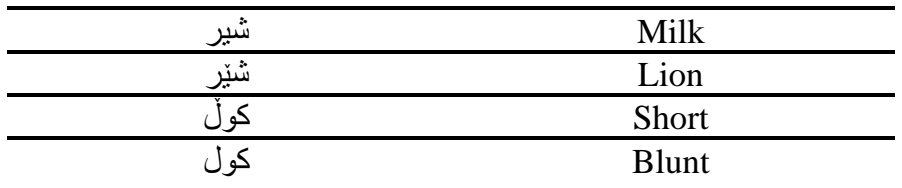

5- Idiomatic Dialogue Expressions: Since some idiomatic expression in Kurdish language are common, but others are less common, it becomes challenging when replying to a question by the bot. The following two expressions have a close meaning using different words:

$$
\begin{aligned}
& \text { Good Morning } \\
& \text { Morning of Light }
\end{aligned}
$$

\section{LITERATURE REVIEW}

Natural language processing (NLP) is new for Kurdish Language, so it is hard to find NLP works on Kurdish in the literature. Therefore, we review some researches that are close to the Kurdish Language such as the Arabic language.

An artificial intelligent agent chatbot for Kurdish Language has been proposed in [5] by using Artificial Intelligent Markup Language (AIML) on the free and opensource platform Pandorabots with a Facebook account. It can answer queries in Kurdish. This system takes the input in text format, then it displays the results in text and provides accurate and quick answers to users.

Writing style of Arabic language is close to that of Kurdish. In [6], an Arabic chatbot for children with Autism Spectrum Disorder (ASD) is developed based on pattern matching (PM). A new Arabic short text similarity (STS) measure is used to extract facts from user's responses to match rules in scripted conversation in a particular domain (Science). The researcher proposed the system on grammatical and morphological.

The first chatbot using for an Arabic dialect was presented in [7] exploring each challenge that faces the creation of conversational agents. It uses the Egyptian dialect of the Arabic language. The researchers illustrate several solutions and explain all elements of BOTTA Chatbot. The database of BOTTA is available to all researchers that are working on Arabic chatbots or the languages close to Arabic in their writing styles such as Kurdish, Urdu and Persian.

In the research proposed in [8], several obstacles and challenges that need to be resolved when developing an effective Arabic chatbot is presented. This is important for other languages that use an alphabet close to the Arabic language alphabet.

\section{THE PROPERTIES OF THE KURDISH LANGUAGE}

The Kurdish language is the backbone of this research, so we define and introduce this language, we especially focus on the Central Kurdish (Sorani) branch.

Kurdish (Kurdish: Kurdí, كوردى, Kurdî) language is a branch of Indo-European family of languages. But dialects of Kurdish are members of the Indo-Iranic languages of the northwestern subdivision. The Kurdish language is not dependent language because it has all features of languages such as historical development, continuity, grammatical system and rich living vocabularies [9]. The Kurdish language belongs to the "Median" language or "ProtoKurdish". People of Kurdistan speak several dialects of the language. Kurdish language dialects are [10]:

1) Nordic Kurdish dialects, also called Kurmanjí and Badínaní. 
2) Central dialects, also called Soraní

3) The Southern Kurdish dialects, also called Pehlewaní or "Pahlawanik".

The other two branches of Kurdish language are Dimílí also called "Zaza” and Hewramí also called Goraní. According some references about linguistic, the southwestern branch of the Indian and Iranian languages of the Lurrí (Luri) branch is classified as a sub branch of Kurdish [9].

The Kurdish nation is divided among five countries: Iraq, Iran, Turkey, Armenia and Syria. Kurdish literature was written in Arabic, Persian or Turkish, although the Kurdish language, written in Central Kurdish (Sorani) and Kurdish Latin Alphabet script, began to appear in the seventh century AD. Nowadays, Kurdish is written in three different writing styles.

1) The Iraqi and Irani Kurdish are using Central Kurdish alphabet, for example: كوردى.

2) The Kurdish of Turkey and Syria use Kurdish Latin alphabet, for example: Kurdî.

3) The Kurdish of Armenia use Cyrillic alphabet, for example: pnnh.

The letters are 34 but the sounds of Kurdish language are 37 for central Kurdish alphabet, but Kurdish Latin alphabet is 31 letters commonly [11], as show in Table 1. In Sulaimani and Kirkuk, the letter D is often softened to the point of being inaudible. The most prominent example of this case is the present modal prefix " دهو":

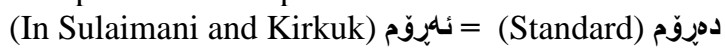

In Kurdish language, especially in Sorani dialect, no words begin with "ر", all initial Rs are trilled "ر,"[12] [13]:

$$
\text { روزَّار = روّزَّار }
$$

Generally, the letters of Kurdish language are pronounced as written that is divide in two parts: Vowel Letters: - it is consisting of long and short vowels as we present as:

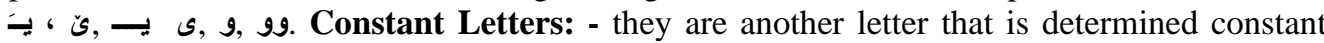
sound, look the table 1 . The words are constructed using combine of two letters or more [13] [14]. According the parts of speech and syntax, Kurdish language words classifies to 8 parts:

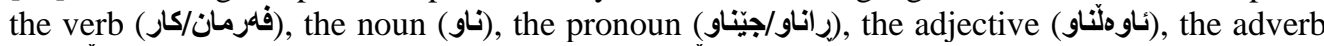

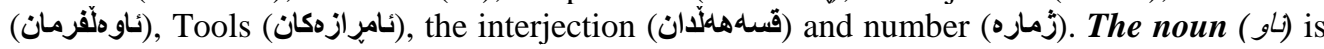

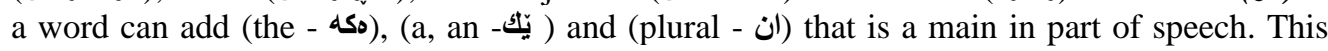
words that name of people, thing and place. It is not related to the time.

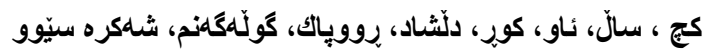

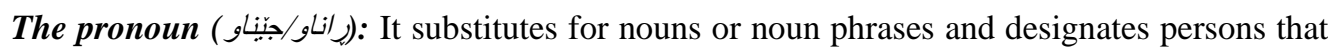
is very important because it is commonly used such as . Generally, it is divided into: personal pronoun such as possessive pronouns is divide into fourth group

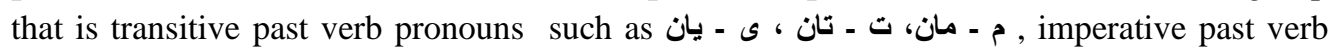

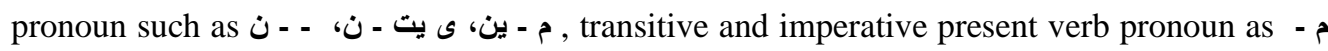

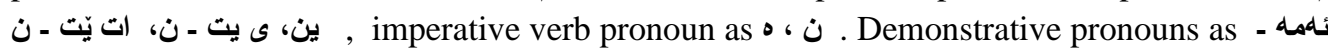

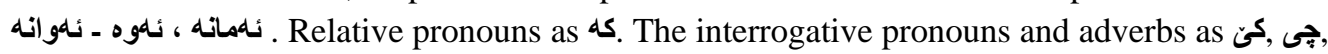

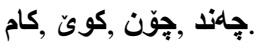

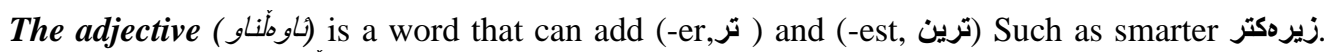

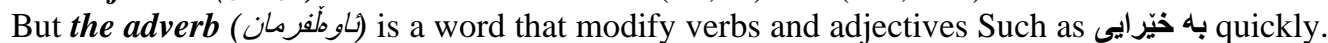
The tools (نامرازمكان) is a word that use to any causes and to create relations between words or

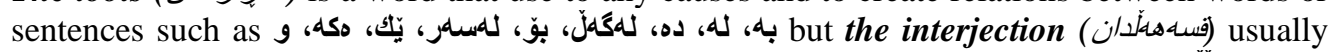

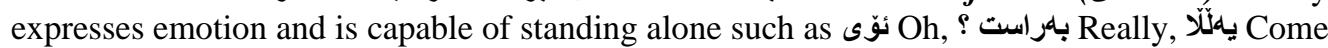


on! The number (رماره) is consisting of cardinal and ordinal number. Finally Verb (فرمان/كار) is an expresses existence, action, or occurrence. [14] [13] [15] [16] [17] [18] [19]

Table 1 : The table of Kurdish letters alphabet, Central Kurdish (Sorani) and Kurdish Latin alphabet.

\begin{tabular}{|c|c|c|c|c|c|}
\hline \multicolumn{3}{|c|}{ Central Kurdish alphabet } & \multirow[t]{2}{*}{ Kurdish Sound } & \multicolumn{2}{|c|}{ Kurdish Latin alphabet } \\
\hline NO. & Sorani & Examples & & Examples & Letter \\
\hline 1 & 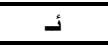 & ائيش & $/ \mathrm{a} /$ & Amed; zana & $\mathrm{A}, \mathrm{a}$ \\
\hline 2 & 1 & ئاوات & /a:/, long a & Batman; kellebab & $\mathrm{B}, \mathrm{b}$ \\
\hline 3 & ب & باران؛ داب & $/ \mathrm{b} /$ & Urdun; dund & $\mathrm{C}, \mathrm{c}$ \\
\hline 4 & 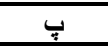 & يُار؛ قُابٍ & $/ \mathrm{p} /$ & Çoman; kiç & Ç, ç \\
\hline 5 & $ت$ & تاو؛ بيت & $/ \mathrm{t} /$ & Dihok; berd & $\mathrm{D}, \mathrm{d}$ \\
\hline 6 & ج & جام؛ تاج & $\mid \widehat{d} 3 /$ & Erzirrom; bere & E, e \\
\hline 7 & ङ & جاو؛ خاج & $\widehat{\mathrm{tg} /}$ & Êwan, pêrê & $\hat{\mathrm{E}, \hat{\mathrm{e}}}$ \\
\hline 8 & $\tau$ & حهيران؛ حسسار & $/ \mathrm{h} /$ & Firat; def & $\mathrm{F}, \mathrm{f}$ \\
\hline 9 & $\dot{\tau}$ & خاك؛ ناخ & $/ \mathrm{x} /$ & Gever; deng & $\mathrm{G}, \mathrm{g}$ \\
\hline 10 & د & داس؛ ئازاد & $/ \mathrm{d} /$ & Hewlêr, Ah & $\mathrm{H}, \mathrm{h}$ \\
\hline 11 & $\mathrm{~J}$ & برين؛ بير & $/ \mathrm{r} /$ & Sirinçik & $\mathrm{I}, \mathrm{i}$ \\
\hline 12 & J & رِاست؛ مهز & Bold /R/ & Îlam, sînî & $\hat{\mathrm{I}}, \hat{\mathrm{I}}$ \\
\hline 13 & $j$ & زانست؛ ناز & $\mid \mathrm{z} /$ & Jawero; kîj & $\mathrm{J}, \mathrm{j}$ \\
\hline 14 & $\dot{j}$ & زيار؛ كيز & $13 /$ & Kobanê; erk & $\mathrm{K}, \mathrm{k}$ \\
\hline 15 & س & سارد؛ كراس & $/ \mathrm{s} /$ & Laliş; mel & $\mathrm{L}, \mathrm{l}$ \\
\hline 16 & ش & شين؛ باش & $\mid \mathrm{g} /$ & Mehabad; dem & $\mathrm{M}, \mathrm{m}$ \\
\hline 17 & $\varepsilon$ & عيّراق؛ دهعبا & $/ \mathrm{gh} /$ & Nisêb & $\mathrm{N}, \mathrm{n}$ \\
\hline 18 & $\ddot{\varepsilon}$ & غونجهـ؛ قُوناغ & $/ \mathrm{gh} /{ }^{\prime}$ & Pawe; esp & $\mathrm{P}, \mathrm{p}$ \\
\hline 19 & ف & فيل؛ ماف & $/ \mathrm{f} /$ & Oremar; boso & $\mathrm{O}, \mathrm{o}$ \\
\hline 20 & ث & قيَان؛ حهقده & $/ \mathrm{v} /$ & Qûçan; deq & $\mathrm{Q}, \mathrm{q}$ \\
\hline 21 & ق & قير؛ تاق & $/ \mathrm{Q} /$ & dar & $\mathrm{R}, \mathrm{r}$ \\
\hline 22 & 5 & كانى؛ يُيك & $/ \mathrm{k} /$ & Ranye; perr & RR, rr \\
\hline 23 & 3 & كَا؛ سينگ & $/ \mathrm{g} /$ & Sine; kras & $\mathrm{S}, \mathrm{s}$ \\
\hline 24 & J & لاو؛ ديل & $/ \mathrm{l} /$ & Şengal, baş & Ş, ş \\
\hline 25 & $j$ & 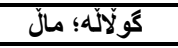 & Bold /L/ & Tirbesipî; kat & $\mathrm{T}, \mathrm{t}$ \\
\hline 26 & 5 & مار؛ سام & $/ \mathrm{m} /$ & Urdun; dund & $\mathrm{U}, \mathrm{u}$ \\
\hline 27 & ن & ناو؛ بان & $/ \mathrm{n} /$ & Ûrmiye, sûtû & $\hat{\mathrm{U}}, \hat{\mathrm{u}}$ \\
\hline 28 & هـ & هيوا؛ بههزه & $/ \mathrm{h} /$ & Vêtnam; bav & $\mathrm{V}, \mathrm{v}$ \\
\hline 29 & 0 & هلَّه؛ هلَّوزْه & $/ \mathrm{e} /$ & Wan; naw & $\mathrm{W}, \mathrm{w}$ \\
\hline 30 & 9 & وانه؛ داو & $/ \mathrm{u} /$ & Xaneqîn; qonax & $\mathrm{X}, \mathrm{x}$ \\
\hline 31 & وّ & دوّ؛ دوّشَاو & $/ 0 /$ & Yêrîvan; key & $\mathrm{Y}, \mathrm{y}$ \\
\hline 32 & وو & دوو؛ بوو & /u:/, Long /u/ & Zaxo; berz & $\mathrm{Z}, \mathrm{z}$ \\
\hline 33 & s & ياد؛ دايه & ii/ & & \\
\hline 34 & s & ديّ؛ ريّي & Bold i & & \\
\hline
\end{tabular}

The sentences are the largest unit in syntax of Kurdish language that are consisting of above part of speech as (subject, object, adverbial, adjunct, complement and verb).

$$
\text { - هيْمن رِادهكات Hemin runs }
$$

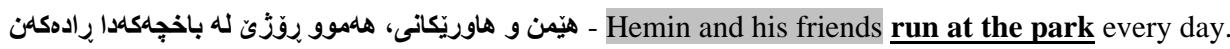

In addition to the transitive verb and the non-transitive verb, there is a third type of verb called the connecting verb. The word (or phrase) that accompanies a connecting verb is not an object, but a complement. The subject complement can be a noun, an adjective or a preposition. most common linking verb is " بوون ", which is equivalent to "to be” in English.

- Chro is lecturer. جروّ له زانكوّيه - Chro is in university. 
The order of components of each Kurdish sentences are بكهر subject, بكركار object and كار (فرمان) verb. Generally, the tense in Kurdish language are present and past [20] [21] [13].

Table 2: Table of Kurdish language tenses

\begin{tabular}{|c|c|c|c|}
\hline $\begin{array}{c}\text { كات } \\
\text { Tense }\end{array}$ & جوّر & $\begin{array}{c} \\
\text { Rule } \\
\end{array}$ & $\begin{array}{c}\text { نموونه } \\
\text { Example }\end{array}$ \\
\hline \multirow{4}{*}{ 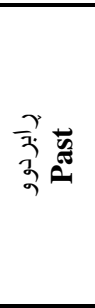 } & Simple & رِركَى ريرابردوو + جينّاو (راناو) ى لكاوو & 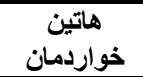 \\
\hline & 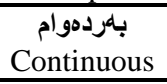 & ده +ردگى يرابردوو + جينّاو (راناو) ى لكاوو & د دهماتخوارد \\
\hline & $\begin{array}{c}\text { تهواو } \\
\text { Perfect }\end{array}$ & رِدىى يرابردوو +بوو+ جيّناو (راناو) ى لكاوو & خواردبووينان \\
\hline & $\begin{array}{l}\text { مدرجى } \\
\text { Conditional } \\
\end{array}$ & ب+ رِكَى يرابردوو + جينّاو (راناو) ى لكاوو+ايه & بمانخوارددايه \\
\hline \multirow{5}{*}{ 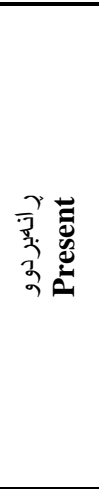 } & 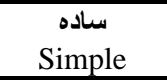 & ده + رهكَى دا هاتوو + جيّناو (راناوو) لكاوو & دنونوسين \\
\hline & $\begin{array}{l}\text { ت تلهواو } \\
\text { Perfect }\end{array}$ & 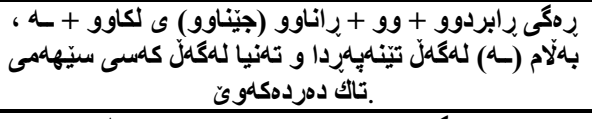 & خواردوومانه \\
\hline & $\begin{array}{l}\text { مةرجى سناده } \\
\text { Simple } \\
\text { Conditional } \\
\end{array}$ & ب + يرهى داهاتوو + رِاناوو (جيناوو)ى لكاوو & 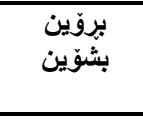 \\
\hline & 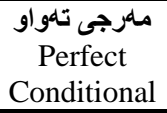 & يرهى يرابردوو + ب + رياناوو (جيناوو) ى لكاوو & 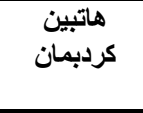 \\
\hline & $\begin{array}{c}\text { داخوازى } \\
\text { Imperative }\end{array}$ & 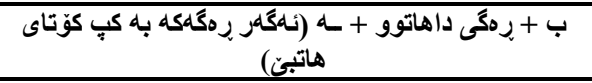 & بنووسو \\
\hline
\end{tabular}

3. NATURAL LANGUAge Processing FOR KURDiSh LANGUAGE

Natural language processing (NLP) is branch of linguistics, computer science, and artificial intelligence that helps computers understand, interpret and manipulate human language [22] However, NLP was originally known as Natural Language Understanding (NLU), it is now well understood that although the goal of NLP. NLU is real, it has not yet been achieved. But the main goal of NLP is "to accomplish human-like language processing". [22] NLP have a challenge to developing a program that understands natural language is a difficult problem. NLP has more application such as: Searching and indexing for large text. Word processor software. Information retrieval. Text categorization using classification. Text summarization software automatically. Question Answering (QA) Applications. [23]

To understanding and applied the NLP to Kurdish language, both things are necessary: the first one is Kurdish language component and grammar. The second one is component of NLP that is divided into Natural Language Understanding (NLU) and Natural Language Generation (NLG) [24] The main techniques of NLP are syntax analysis and semantic analysis:

First - Syntax Analysis: it is referring to the sentences that words arranged in this structure of text and they have grammatical meaning. Also known as parsing. It has more techniques:

Tokenization and pattern matching are an essential operation used to break up a string into words, punctuation marks, numbers and other items. For example:

“Dr. Hawzhin, Mr. Sherko Barznji”, said Kurdistan, introducing us. can be tokenized as in the following, where each token is enclosed in single quotation marks:

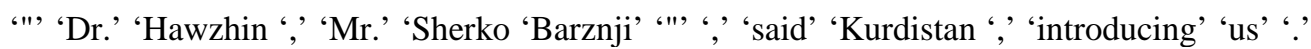
The important task in this step is finding the boundary of words. In Kurdish language, the 
boundary of words can determine using the fully separated by space, separated by half - space or be related to each other.

$$
\text { من بِّبوّرى بهرنامه سازيم }
$$

In the first sentence, the بهرنامه سازيم is two words, if we determine by space separator, but in

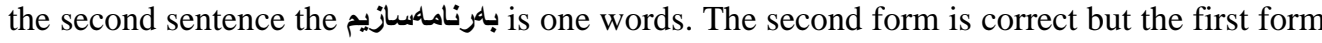
in incorrect.

Parts of speech (POS): Another NLP task is speech tagging to identify the part of speech for every word and categorized of words that have same properties of grammatical, for example:

\begin{tabular}{|c|c|c|c|c|c|}
\hline Kurdish sentence & & قوتابخانه & بوّ & دهروم & من \\
\hline English sentence & & School & to & go & $\mathrm{I}$ \\
\hline POS Tags & Punctuation & Noun & Preposition & Verb & Pronoun \\
\hline
\end{tabular}

Table 3: POS tag for Kurdish sentences example

Lemmatization is a common technique to solve words in the form of their dictionary, which requires a detailed dictionary in which the algorithm can search for words and link them to their respective prepositions.

$$
\text { جوون -- دمجٍ -- دمجووم -- بجوّ --جوو بوو -جووه، باش -- باشتر -- باشترين }
$$

Stemming: it is a process to convert from inflected or derivates words to steam, base or root form. commonly, it removes all the suffixes and affixes based on some predefined linguistic rules.

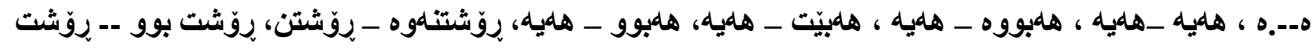

Stemming for Kurdish language classify to verbal stemming and non-verbal steaming.

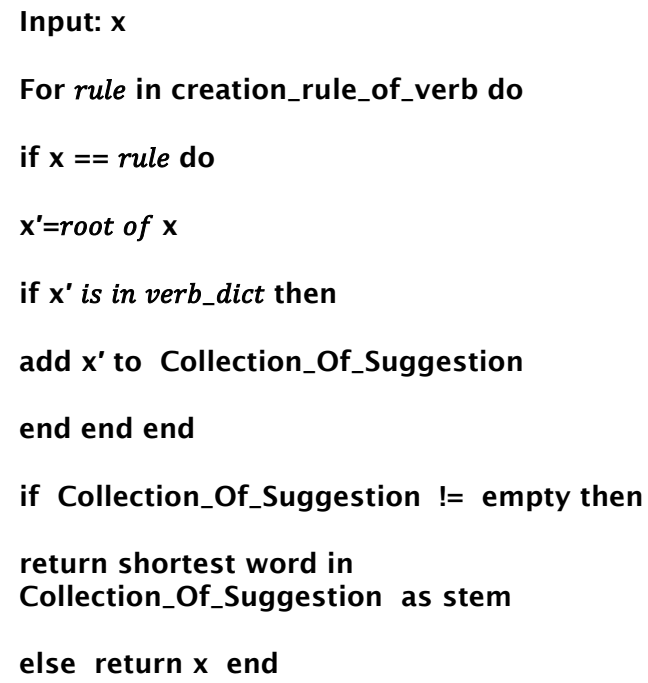

Figure 1: Algorithm of verbal stemming in Kurdish language

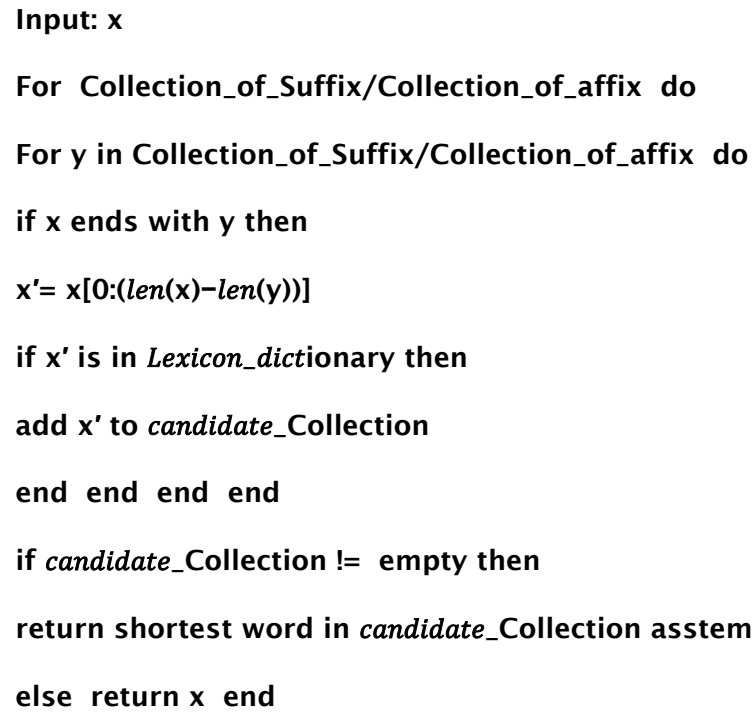

Figure 2: Algorithm of non- verbal stemming in Kurdish language 
Parsing: This includes performing grammatical analysis for the sentence provided. The syntactic parser usually receives a sentence containing margins as input and returns a parsed syntax as output.

Second - Semantic Analysis: it is referring to the meaning that is sent by text and focus of meaning identification of language. It is the difficult part of NLP that has not yet been fully solved. Some computer technique and algorithms are created to understand and interpretation of words. Common techniques are: Name Entity Recognition (NER) is a most common task in semantic analysis that is extracting entities from text. The entities can be name, place, email address, and more. Natural language generation, This includes using a database to obtain semantic goals and convert them into human language. It is a special technique that is used to convert from plain text to raw structured data.

[25] [26] [24] [23] [27] [28] [29] [30] [31]

\section{CHATBOTS}

The chatbot is a software agent based on artificial intelligence which is used in conversation between users and software robot [2]. This agent can interact with human carefully using NLP as a basic to produce this process [32]. Chatbot is a simulation of human user conversations especially over the Internet, but it is possible to apply it as an offline software for specific purposes, such as travelling guide, education or self-learning of languages [33]. The idea of chatbot belongs to the Alan Turing test [34].

Eliza chatbot is the first agent that was developed by Joseph Weizenbaum in AI Laboratory at Massachusetts Institute of Technology (MIT) in 1966. [35] [36]. Parry is another chat bot that was created by the psychiatrist and computer scientist Kenneth Mark Colby at the department of Psychiatry in Stanford University in 1972 [35]. The chatbot Jabberwacky was created by British developer Rollo Carpenter in 1988. It was intended to simulate a natural human dialogue [1]. In 1992, Dr. Sabaitso chatbot was created by Creative Labs for MS-Dos. In 1994, the term of chatbot was coined. In 1995, ALICE was created by Richard Wallace, which is an acronym for "Artificial Linguistic Internet Computer Entity". In 2001, Wallace published AIML specifications [2] [37].

Smarter Child was an intelligent chatbot created in 2001; it has some features such as accessing data quickly and funny personalized conversations [1]. In 2006, the Watson chatbot was created by IBM, it is a question answering system. in 2010, Siri was created by Apple as part of the Apple operating system; it is a text and voice chatbot [1]. In 2012, MITSUKU chatbot was created by Steve Worswick. It uses AIML language to understand the user's response [38]. In the same year, the Google Now was developed by Google using NLP [39]. The Alexa chatbot was developed in 2015 by Amazon, it is capable to interact with voice and it uses algorithms of NLP to receive sounds, recognize and respond [40]. In the same year, Microsoft Company created Cortana bot for mobile and personal computers that use Windows operating system. [41]. In 2016, social networking site Facebook provided a platform of messenger that allows developers to build a bot for Facebook users [42].

\subsection{Types of Chatbot}

Chatbot classify in some classification to determine chatbot types. Common categorized of chatbot according different parameters are: - The knowledge domains that are categorized based on the knowledge they have access to or the amount of data they receive. The Providing services is another classification of bots are based on the branch of knowledge that deals with the amount of space that people feel it necessary to set between themselves and others In The goal's classifications, chatbots are categorized based on the early objectives that is aim to achieves. 
The processing of input and method of response generations: the categorization of chatbot are according methods that are divides to 2 models: The Rule Based Approach (RBA), the chatbots trains based on predefined set of rules that was trained in the early stages to answer questions. Self - Learning Approach (SLA), the chatbots can learn on their own using the advanced technologies such as AI and Machine Learning. It is divided into:

1- Retrieval-based approach of Chatbots has much easier structure to create bots and provide more predictable result. because it is applying functions on predefined patterns of input and responses that uses heuristic method to deliver suitable response. Now, this approach is very common and more practical.

2- Generative based approach of Chatbots are the hereafter of chatbots that build a smarter chatbot. Unfortunately, it has not wide range to use by developer, because It is now more in laboratories.

If chatbots are about general topic conversation and response properly, it is opened domain chatbots. Otherwise, if chatbots are about specific topic and specialized title, it is closed domain.

[43] [44] [45] [46]

\subsection{The design techniques of chatbots}

The design techniques used by chatbot developers are:

1) Parsing: it is used to analyze and process the input from users by using several functions of NLP, such as Python NLTK tree [47].

2) Artificial Intelligence Markup Language (AIML): It is the main technique that is used to design chatbots. [48].

3) Chat Script: This is a technique that helps in cases when no matches return from AIML. It makes the best syntax to build a reasonable default answer. It offers a set of features such as variable concepts, facts, and and/or logic operations [47].

4) Pattern Matching: this technique is about the artificial intelligence that is used to design the chatbots to match the input from users with the database-stored answers and then returning the identical response [49].

5) SQL and relational Database: A method that has recently been used in Chatbot design to remember Chatbot previous conversations.

6) Markov Chain: Chatbots are used to create responses that are more likely to be useful and therefore more accurate. The Markov chain idea is that there is a probability of occurrence for any letter or word in the same textual dataset [3] [50].

\subsection{AIML - Artificial Intelligence Markup Language}

AIML is a standard of artificial intelligence markup language that is a language for artificial intelligent applications creation. It built based on extensible markup language (XML) dialect invented. The AIML is very important to AI software agent, especially natural language software agent development because it use in structure of semantic and syntax as theoretical structure. AIML was developed during 1995 to 2000 by the Alicebot free software community and Dr. Richard S. Wallace, the AIML is created using the techniques of pattern recognition or pattern matching. It is manipulated to natural language modeling for conversation between human and chatbots that use simulation response approach. [51] The main purpose of AIML is the definition of some knowledge that chatbot has [52].

According the technical of speaking, AIML basic anatomy and structure is tag. Each tag consists of open/start tag and close/end tag as following example:

$<$ Tagname $></$ TagName $>$

AIML has some static tag. Category, pattern, and template are three most common important tags. The category tag is used to knowledge unit definition of conversation. The tag of pattern is used to identify the user input and the template tag is used to response to user input 
specifically. The three tags and all AIML tags must be wraps and write between the open/start

AIML tag and close/end

$<$ aiml version = "1.0.1" encoding = "UTF-8"?>

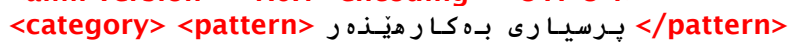

<template>>>ltemplate> >/category>

$</$ aiml $>$

Other common AIML Tags are the following tags: $<$ random $>$

1- $\quad<$ random $>$ tag: is used to get random response of same input differently. This tag is used with $<\mathrm{li}>$ tag to carry items of different response:

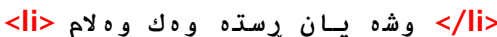

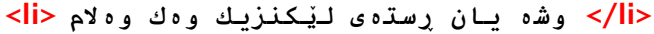

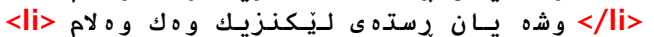

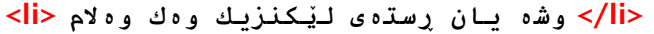
$<$ /random $>$

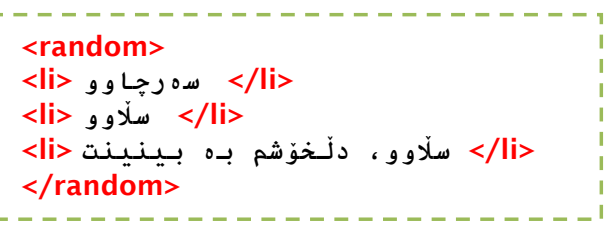

2- $\quad<$ set $>$ and <get> tags: are used with variables. The set tag is used to set value in a variable but get tag is used to get value from a variable:

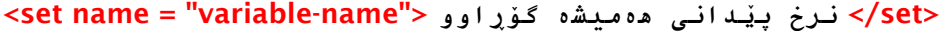

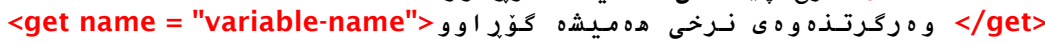

3- <that> tag: is used to respond base on the context:

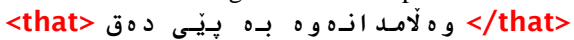

4- <break> tag: it is used to create line break.

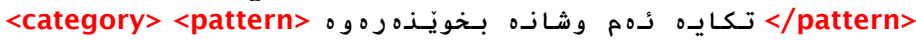

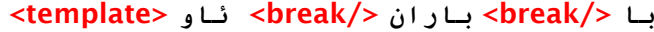

$</$ template $></$ category $>$

5- Button tags: they are some tags that are used to create a button to apply specific action, see the following:

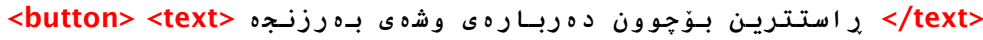

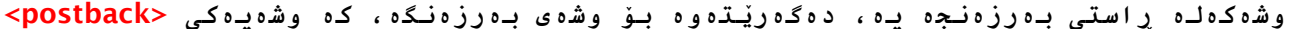

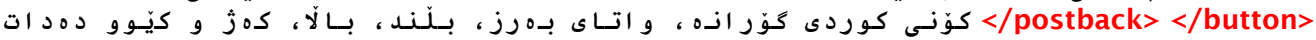

The text tag is optional that is use to preview a text that appear on the button, but content of postback tag is appear by chatbot when user click on the name of button. Sometime the developer of chatbot use the URL tag.

$<$ button>

>text>>ltext>

$<$ url> https://barzanja.com</url>2

$</$ button>

6- Quick reply tags: these tags are other rich media element with text and postback such as post back button The text tag is appeared on the reply response but the post back tag send message to bot. <reply>

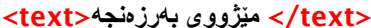

$<$ postback>Barzanja History</postback> $<$ /reply $>$

7- <image > tag: it is a rich media element tag that is used as advanced AIML chatbot implementation to solve some problem and to chatbot response for user. <image> barznja.png </image >

8- $\quad<$ video $>$ tag: this tag is used to allow chatbot to send back video as response: $<$ video>barzanja.mp4</video>

9- Card tag: it is used to wrap around other tags to collect all elements such as Image tag, buttons tag, title tag, sub title tag, text and so on. The result is containing navigation all of rich media elements:

$<$ card $>$

<image>barznja.png</image>

<title>title>

<subtitle>>subtitle>

$<$ button>

<text> ميّزووى بكرزهنجه > > text>

<postback>Barznja History</postback>

$<$ /button>

$<$ button>

$<$ text>ltext>

<postback>Zanayan</postback>

${ }^{2}$ This website URL is not existing in Internet.

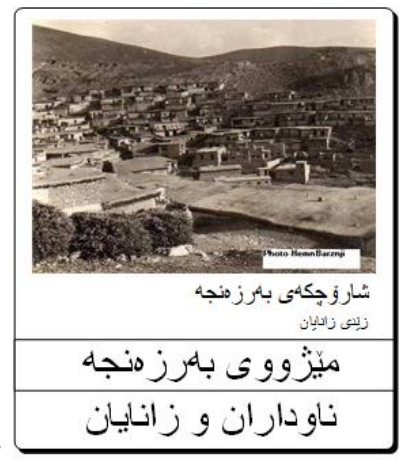


$<$ button $>$

$<$ card $>$

[54] [55] [56] [57]

\subsection{Chatbot platforms and construction components}

We created a chatbot to experiment the Kurdish language problems with natural language processing techniques, then we suggest solutions to solve these problems. We use chatfuel platform to create a chatbot for Barzanja village that consists of 300 questions and answers to apply this work. There are several software platforms available to create chatbot agents. Common examples of AI chatbot platforms are: Chatfuel, Bot Framework by Microsoft, Wit.ai, Manychat, Dialogflow, IBM Watson Powered by Neural Network,Botsify, Reply.ai, Aivo, Pandorabots, Boost.ai, MobileMonkey [58]. Table 4 compares between three of these platforms [59] [60] [61].

Table 4: This table is differentiation between Microsoft bot, Dialogflow and IBM Watson

\begin{tabular}{lll}
\hline \multicolumn{1}{c}{ Microsoft Bot } & \multicolumn{1}{c}{ Dialogflow Bot } & \multicolumn{1}{c}{ IBM Watson } \\
\hline Developed by Microsoft & Developed by Google. & Developed by IBM. \\
\hline $\begin{array}{l}\text { It has open source SDK that is } \\
\text { used to test the bot before } \\
\text { deployment in to the channel. }\end{array}$ & $\begin{array}{l}\text { Inline code and multi- } \\
\text { functional intelligent } \\
\text { integrations. }\end{array}$ & $\begin{array}{l}\text { Watson offers pre-trained and } \\
\text { pre-integrated architecture }\end{array}$ \\
\hline $\begin{array}{l}\text { It is support text, SMS, Video } \\
\text { and Speech. }\end{array}$ & $\begin{array}{l}\text { It is support natural language } \\
\text { and speech to text } \\
\text { conversations. }\end{array}$ & $\begin{array}{l}\text { It is support natural language } \\
\text { processing and question- } \\
\text { answering system }\end{array}$ \\
\hline interact with skype, slack, etc. & interact with Google, Alexa, etc & detect the disease \\
\hline AI and machine learning bot. & machine learning and AI bot. & Neural network and AI bot. \\
\hline
\end{tabular}

\subsection{Chatfuel platform}

Chatfuel is one of the best platforms to create chatbots. It provides a WYSIWYG interface that allows users to create chatbots [62] [4]. So, it is a useful and important platform since it provides AI technology to script conversations interactively. Several companies use chatfuel platform, such as Adidas, Uber, TechCrunch, British Airways, Goal.com, Volkswagen, and MTV [3].

Other main properties of the chatfuel platform are: Chatfuel provide templates and prebuilds to create chatbot from. Chatfuel makes chatbots directly by asking users to choose from suggested topics to produce a meaningful conversation. [58] [4]. The design and implementation of bots consist of the following basics and important components:

1) Automate: it is an important part to create each bot, consists of the following:

A- Block: it is the main part of the bot that is used as the base to link the cards. The blocks are like webpage of websites [63], [4].

B- Cards: it is the block content that include elements such as text, images, galleries, videos, audios, comments, quick replies, attributes, and so on.

C- Plugin: it is a small program to enhance the bot [58].

2) Live chat: It is an important part to monitor active users at the time of chatting.

3) AI Setup: This is a special part to enter all possible questions and answers. [63].

The structure of chatfuel is easy for building conversations between human and bot. The user opens the Facebook messenger and then type a phrase or tap a button to start a conversation. The chatfuel engine determine the user's action and then redirect it to a block or text. Then it replies to the user with a correct or the best nearest answer. Figure 3 illustrates those steps.

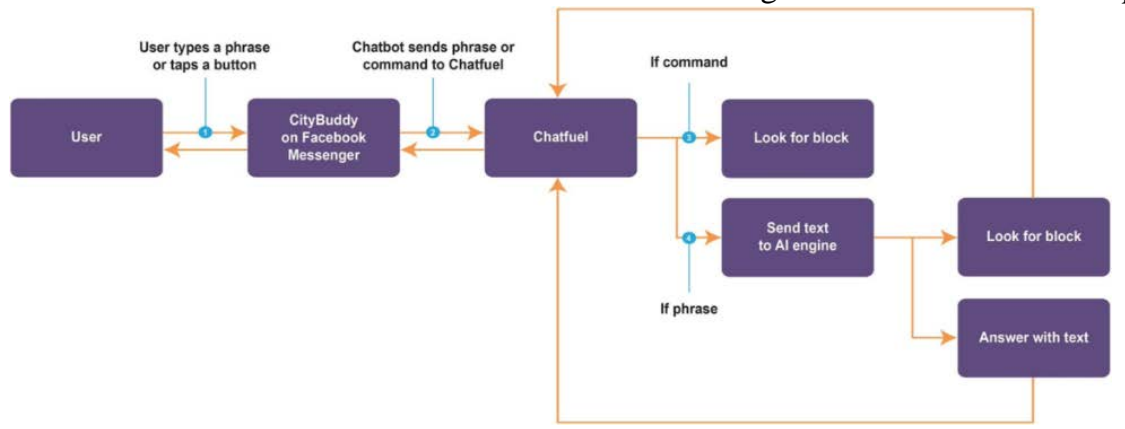

Kurdistan Journal of Applied Research | Volume 5 - Issue 2 - December 2020 | 127 
Figure 3: The general diagram of Chatfuel applications [63]

\section{Propose of BARZANJA CHATBOT}

Barzanja Chatbot is a tourism guide to the religious holy sites in the village of Barzanja for Kurdish language speakers. That we proposed using AIML and Chatfuel as platform. It consists of 300 general and common questions with answers.

Figure 4: The Dashboard of barzanja chat bot
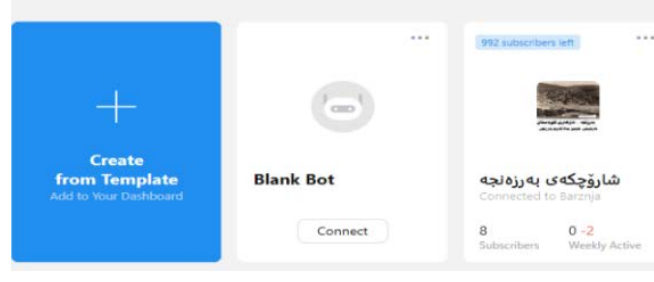

5.1. Barzanja chatbot components

The design and implementation of Barzanja Chatbot software agent consists of blocks, cards and AI setup as the main components.

\subsubsection{Blocks and Cards}

A- Block: We use blocks to prepare answers or to connect them with questions. When a user sends questions, the bot sends to the user these blocks as answers. Other blocks are used for special information that Bot sends to users such as the welcome block; this block appears when a user getting started, while the default answer block is used to reply to a user who sends a question that cannot be recognized by the bot. But block in AIML is a category tag, other all tags are cards that are used between open/start and close/end tag of categories to create component of block such as text, image and video. For example:

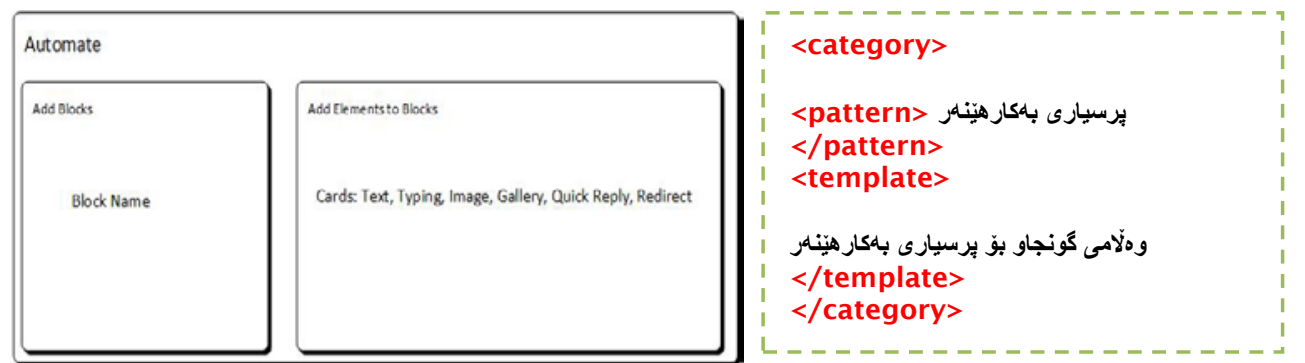

Figure 5: Wireframe diagram of blocks in barzinja chat bot that is consists of block name and cards.

B- Cards:

Common cards of Barzanja Chatbot is text cards, but sometimes we use cards that represent images, galleries, quick replies and so on. Figure 7 and figure 8 examples for block and block contents (cards) with AIML code.

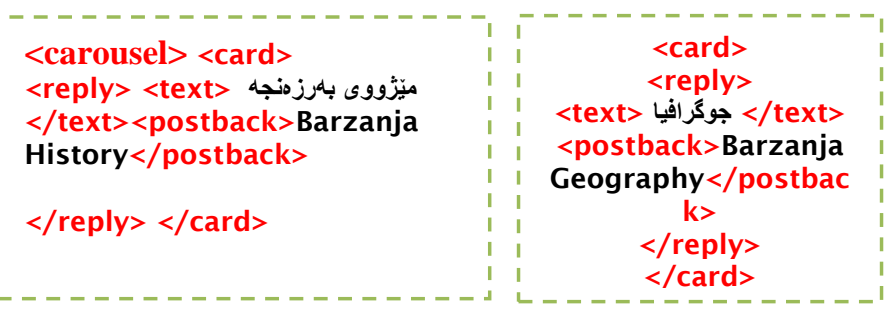

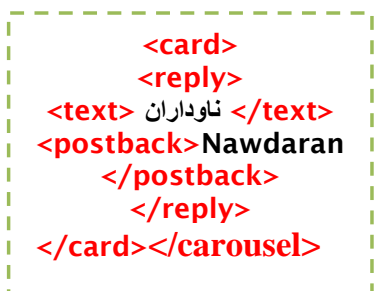




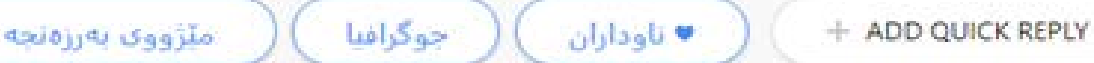

Figure 6: A quick reply card that appears as a suggestion answer by the chatbot to any users.

The GUI of Welcome Message block and AIML of welcome message is a common block and card in a chatbot as the following:
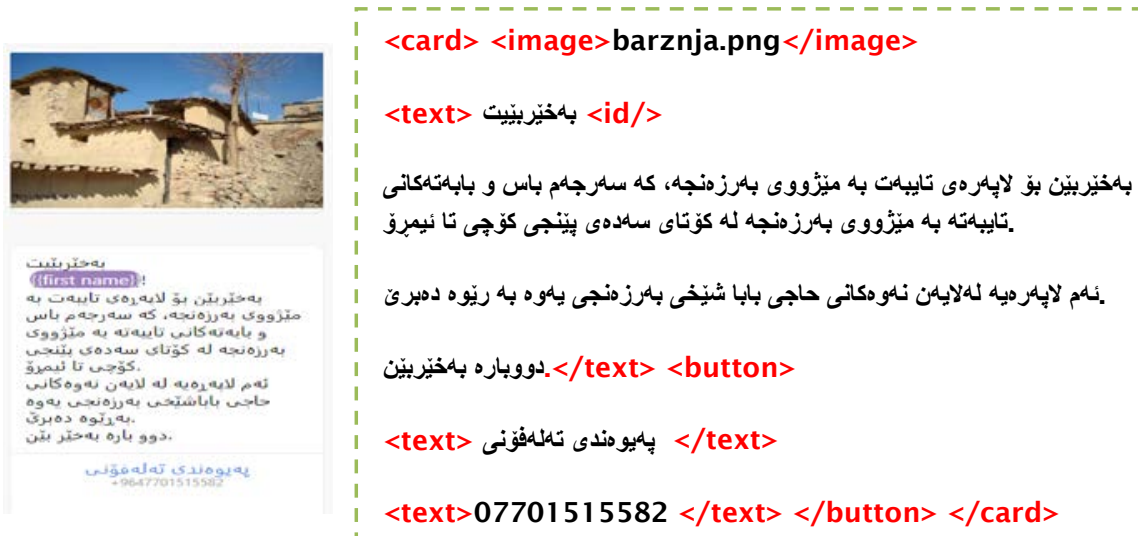

Figure 7: GUI of block and card example

\subsubsection{Set Up AI}

We use this part of the dashboard to enter 300 questions and possible bot answers to reply to users' questions.
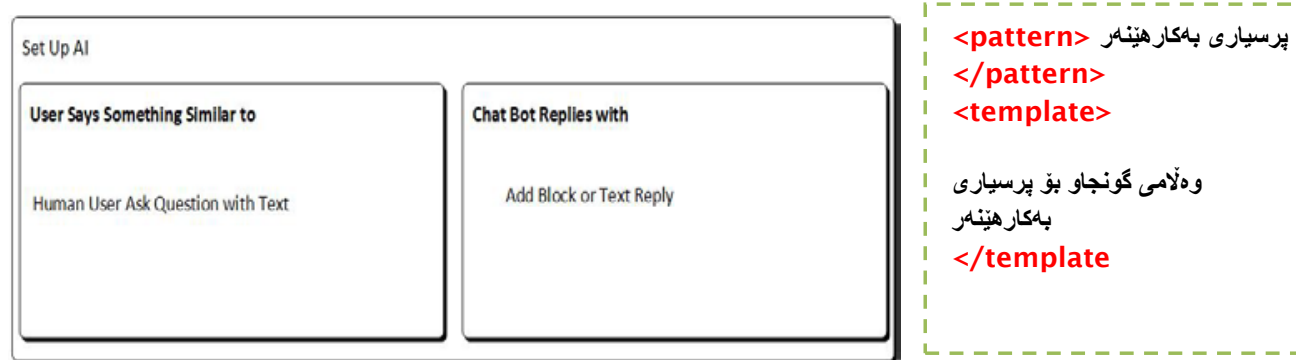

Figure 8: Wireframe diagram of general Set up AI and AIML code to Set up AI

Below AIML codes shows a sample question and the bot's answer.

$<$ category $><$ pattern $>$

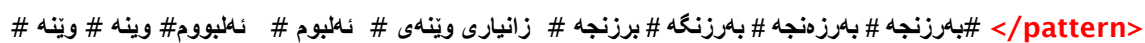

$<$ template $><$ carousel>

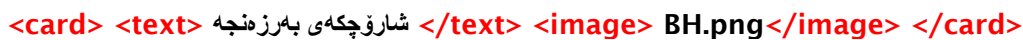

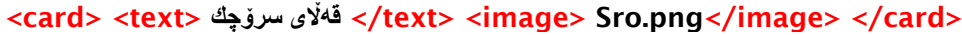

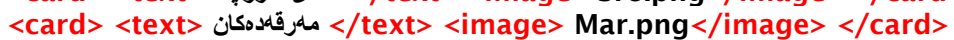

$<$ /carousel $><$ /template $></$ category $>$

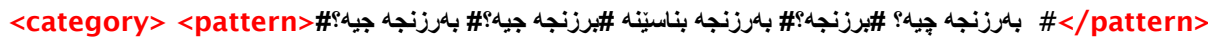

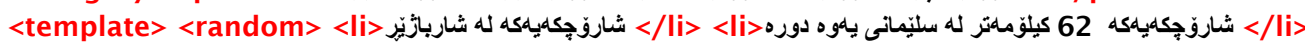

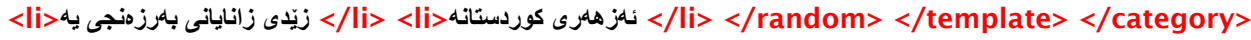




\subsubsection{Live Chat}

We use this component of the dashboard to see the users that connect to the bot and their conversations.

\section{USING AND ANALYZING THE CHATBOT}

After creating all parts and components of the Barzanja chatbot with 300 questions and answers, we test the project with 100 volunteer users. The volunteers of use Barzanja Chatbot according the activity diagram illustrated in Figure 9.

Figure 9: general Activity diagram of chatbot using by users for one cycle

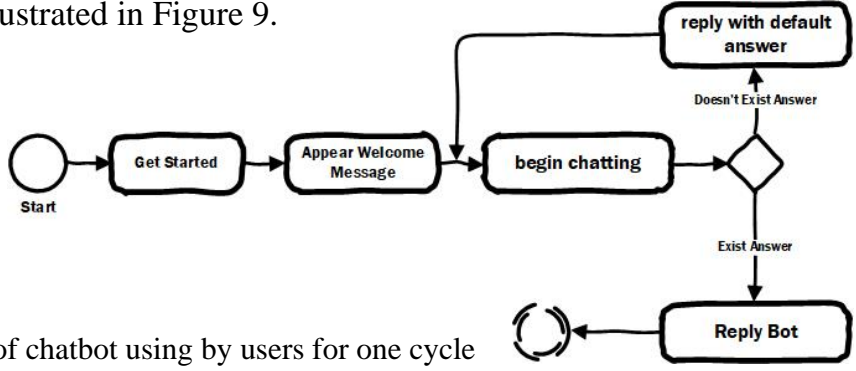

When a user starts a conversation. The system immediately replies by using the welcome message. This welcome message is provided for all users, after that users can start asking questions, for example:

User: سلّاو

Chatbot: سهرجاوو ،خوّتان بناسيّنتن

If the user uses the Kurdish Latin alphabet or English alphabet, the bot cannot understand this message because the system developed for Sorani (Central Kurdish) dialect. So, the bot replies by using the default message:

User question: Sllaw

The Bot answer:

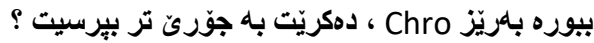

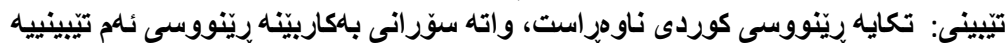

Samples of interaction between users and the Barzanja chatbot via questions and answers are show in Table 5.

\section{RESULTS AND DISCUSSION}

After using and analyzing the Chatbot, we collect user's information to determine the problems in using the Kurdish language with technology, then we analyze the performance of the bot according the users' participation and the bot's response. After creating the chatbot agent, we tested with 100 users, the total results of testing users' participation (as shown Figure 11) are:

- $\quad$ \%25 uses the English alphabet and Kurdish Latin letters. The first question of user starts with English or Kurdish Latin alphabet, for more clearing, we discuss two examples: For example, first user starts to conversation as: Choni? The second user start to conversation as: Çonî?

- $\quad \% 20$ uses the Arabic alphabet letters. The user starts Arabic alphabet to write any جؤنى؟

- \%15 uses mixed typing between Arabic, English letter and Kurdish Latin letters. The question of users is mix in the start of conversation to end of conversation, for more clearly see the following example.The user state conversation using Arabic alphabet, after that the bot say: please use Kurdish alphabet. But user use the English alphabet and so on: 


$$
\begin{aligned}
& \text { ببوره بهريّز Aso ، دمكريتّ به جوَريّ تر ببرسيت ؟ } \\
& \text { تيبينى:تكايه رينينووسى كوردى ناو مبراست، واته سوّرانى بهكاربينه. }
\end{aligned}
$$

Sllaw

- $\% 40$ uses the central Kurdish alphabet (Sorani) via Kurdish Unicode keyboard. All users use Kurdish alphabet to start conversation, then continue until the conversation is finish.

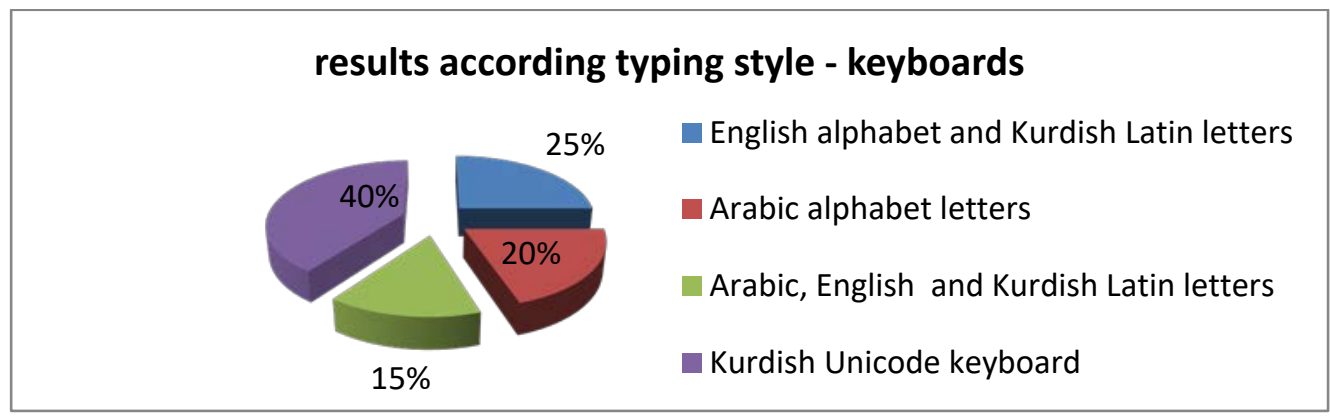

Figure 10: pie chart to determine typing style according users

Sometime other problems may occur, especially when using different keyboard alphabets. To solve those problems, we suggest the following solutions:

To solve the problem of using English alphabet and Latin letters:

A- When the user starts the application, the bot suggests downloading and installing the Central Kurdish Keyboard (Sorani Unicode). The Sorani Keyboard shown in Figure 11 can be used by the Chatbot users in case the Operating System they use does not support Kurdish Unicode.

Figure 11: Wireframe of Central Kurdish (Sorani) Keyboard

B- The user can use the English keyboard to type directly Kurdish text. However, some problems may occur, for example, the number of the English letters is 26, while the number of Kurdish letters is 34. In this case we suggest using some symbols and double letters to express the Kurdish letters that do not have corresponding letters in English alphabet. Figure 16 shows the Kurdish letters and their corresponding English single or double letters, or a letter and an apostrophe.

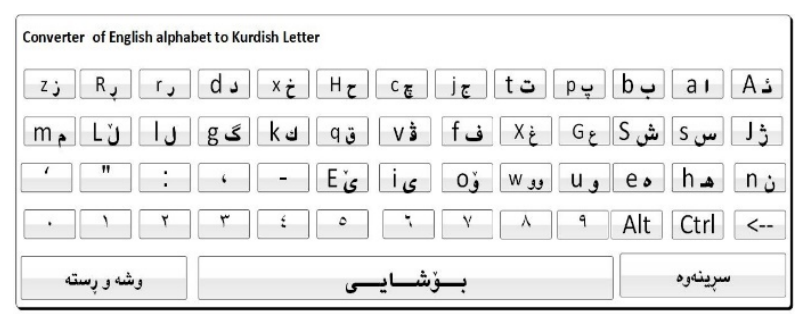


Figure 12: Central Kurdish Keyboard (Sorani Alphabet) to Convert English and Latin alphabe

Table 5: user information about chatting with questions - answers

\begin{tabular}{|c|c|c|}
\hline Name & User questions & Bot answers \\
\hline \multirow{7}{*}{$\begin{array}{l}\text { Chro } \\
\text { Ahmad }\end{array}$} & Sllaw & \\
\hline & & 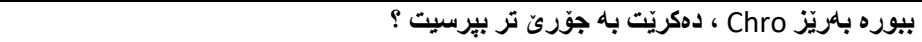 \\
\hline & & 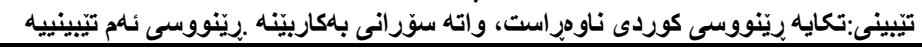 \\
\hline & ئسم كاتهت باش & \\
\hline & & سلهرجاوو \\
\hline & بلمرزنجه جيه ؟ & \\
\hline & & كوَنديّكه له شاربازُّيّر \\
\hline \multirow{2}{*}{$\begin{array}{l}\text { Barzan } \\
\text { Barznji }\end{array}$} & بهرزنجهم بيّ بناسينْه؟ & \\
\hline & & 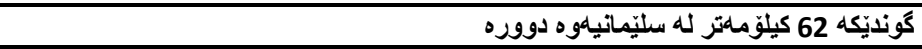 \\
\hline \multirow{4}{*}{$\begin{array}{l}\text { Shano } \\
\text { Barzan }\end{array}$} & سلّاوو & \\
\hline & & 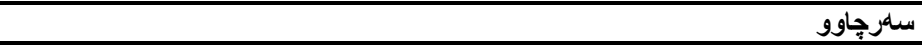 \\
\hline & بهرزنجه جيه ؟ & \\
\hline & & 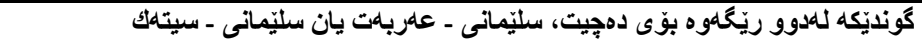 \\
\hline \multirow{4}{*}{$\begin{array}{l}\text { Sherzad } \\
\text { Ahmad }\end{array}$} & 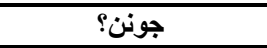 & \\
\hline & & سلهرجاوو \\
\hline & برزنجه جيه؟ & \\
\hline & & كَونديّكه 62 كيلوَمهنتر له سليّمانيهوه دووره \\
\hline \multirow{4}{*}{$\begin{array}{l}\text { Sherko } \\
\text { Ahmad }\end{array}$} & 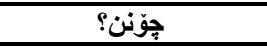 & \\
\hline & & 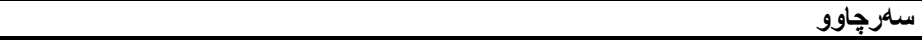 \\
\hline & برزنجه جييه؟ & \\
\hline & & كوَنديّكه له شاربارَيْرِ \\
\hline \multirow{9}{*}{$\begin{array}{l}\text { Arsh } \\
\text { Omer }\end{array}$} & 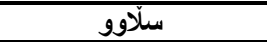 & \\
\hline & & 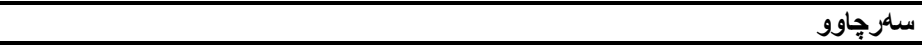 \\
\hline & بهرزنجام بيّ بناسيّنه؟ & \\
\hline & & كو نديّكه 62 كيلوّمهتر له سليّمانيهوه دووره. \\
\hline & Cwgrafiay barznja & \\
\hline & 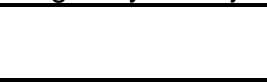 & 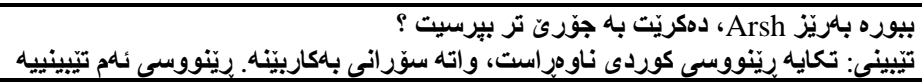 \\
\hline & زانيارى جووكرافي & \\
\hline & & ملباستتت جوكر افياى بهرزنجه يه؟ \\
\hline & باملْيَ & \\
\hline
\end{tabular}

\section{CONCLUSION AND FUTURE WORK}

In this research, we create a chatbot to access information about Barzanja Chatbot automatically 24 hours a day without need to any human intervention. We determine some problems in Sorani dialect of the Kurdish language. Such problems include lack of research on Kurdish language with natural language processing (NLP), Kurdish font disorder, lack of standardized keyboards and writing styles, etc. The proposed chatbot was capable of responding to any question asked by a user even if it has not been recorded previously. This is done by suggesting other methods for asking questions or by providing a default answer. This chatbot has been tested on a specific case study but it can be applied to other areas when automated customer support is required 24/7, such areas include healthcare, education, and 
businesses. In future, we implement autocorrection to return some words to original words, which improves the performance, enhances the availability of the bot, and reduces mismatching and misunderstanding. In addition, developers can provide answers in Arabic alphabet for users who use Arabic keyboards.

\section{REFERENCE}

[1] C. Mahalakshmi, T.Sharmila, S.Priyanka, M. Sastry, D. B. V. R. M. Reddy and M. K. K. Reddy, "A SURVEY ON VARIOUS CHATBOT IMPLEMENTENTION TECHNIQUES," JASC: Journal of Applied Science and Computations, vol. Volume VI, no. Issue I, January 2019.

[2] H. Devarasetti, M. Kamilla, A. R. K, M. C. K. K. Reddy and D. B. V. D. Ramanamurthy., "AI CHATBOTS," JASC: Journal of Applied Science and Computations, vol. Volume VI, no. Issue I, January 2019.

[3] R. M. Sharma, "Chatbot based College Information System," RESEARCH REVIEW International Journal of Multidisciplinary, Vols. Volume-04, no. Issue-03, pp. 109-112, March 2019.

[4] Bc.JakubKř́̌ž, Chatbot for Laundry and Dry Cleaning Service, Brno: Masaryk University Press, 2017.

[5] K. M. Kaka-Khan, Building Kurdish Chatbot Using Free Open, UHD JOURNAL OF SCIENCE AND TECHNOLOGY, 2017.

[6] S. S. Aljameel, Development of an Arabic Conversational Intelligent Tutoring System for Education of Children with Autism Spectrum Disorder, PhD Thesis, Manchester Metropolitan University, 2018.

[7] D. A. Ali and N. Habash, "Botta: An Arabic Dialect Chatbot," the 26th International Conference on Computational Linguistics: System Demonstrations, 2016.

[8] E. S. AlHagbani and M. B. K. , "Challenges Facing the Development of the Arabic Chatbot," First International Workshop on Pattern Recognition, 2016.

[9] P. M. Izady, The Kurds: A Concise Handbook, Harvard University Press, 1992.

[10] D. J. Nebez, Towards a unified Kurdish language, Bamberg: NUKSE publisher, 1976.

[11] D. Sadjadi and M. Ibrahimi, Kurdish language and literature, Saqz: Gutar Press, 1396.

[12] L.O.Fossum, A Practical Kurdish Grammar, THE INTER-SYNODICAL EV.LUTHERAN ORIENT -MISSION SOCIETY, 1919.

[13] D. H. Kim, A Basic Guide to Kurdish Grammar, Culture and Language Institute of Kurdi and Kori, 2010.

[14] D. A. Rokhzadi, Sorani Kurdish Grammar, Kurdistan Publication, Sanandaj, 1389.

[15] D. A. H. Marf, Kurdish Grammar - Morphology, vol. Volume 1, Baghdad: Al-Huriya House , 1998.

[16] D. A.-W. Dzay, Kurdish Morphology, Second Edition ed., Hawler: Salahadin University Press, 2013.

[17] W. M. Thackston, Sorani Kurdish, A Reference Grammar with Selected Readings, Harvard, 2011.

[18] N. Khoshnaw, Kurdish Grammar, Hawler: Salahadin, 2015.

[19] N. Khoshnaw, Kurdish Language Syntax, Hawler: Rojhalat Printing, 2012.

[20] P. D. W. O. Amen, Asoyaky Try Zmanawany, vol. Volume: 1, Hawler: Aras Publication, 2009.

[21] D. Farhadi, Hende Layeni Rstesazy Zmani Kurdi, Hawler: Kurdish Academic , 2013.

[22] E. D. Liddy, Natural Language Processing, NY. Marcel Decker, Inc., 2001.

[23] K. R. Chowdhary, Fundamentals of Artificial Intelligence, Springer Nature India Private Limited, 2020.

[24] D. Khurana, A. Koli, K. Khatter and S. Singh, Natural Language Processing: State of The Art, Current Trends and, India, 2016.

[25] R. Kibble, Introduction to natural language processing, London : University of London , 2013.

[26] A. Copestake, Natural Language Processing, University of Cambridge,, 2004.

[27] E. D. Liddy, Natural Language Processing, Syracuse University Press, 2001.

[28] P. M. Nadkarni, L. Ohno-Machado and W. W. Chapman, Natural language processing: an introduction, J Am Med Inform Assoc, 2011.

[29] J. Hirschberg and C. D. Manning, Advances in natural language processing, science mag, 2015.

[30] E. Cambria and B. White, Jumping NLP Curves: A Review of Natural Language Processing Research, IEEE Computational intelligence magazine, 2014.

[31] T. Hosseinikhah, A. Ahmadi and A. Mohebi, A New Persian Text Summarization Approach Based on Natural Language Processing and Graph Similarity, Iranian Journal of Information Processing and Management, 2018.

[32] J. Bozic, O. A. Tazl and F. Wotawa, "Chatbot Testing Using AI Planning," in IEEE International Conference on Artificial Intelligence Testing (AITest), 2019. 
[33] F. Peters, "Design and implementation of a chatbot in the context of customer support," University of Liège press, 2018.

[34] M. T. ZEMČÍK, "A Brief History of Chatbots," in International Conference on Artificial Intelligence, Control and Automation Engineering (AICAE 2019), 2019.

[35] G. NEFF and P. NAGY, "Talking to Bots: Symbiotic Agency and the Case of Tay," International Journal of Communication 10, vol. Volume 10, 2016.

[36] J. Weizenbaum, "ELIZA — a computer program for the study of natural language communication between man and machine," Communications of the ACM, vol. Volume 9, no. Number 1, January 1966.

[37] S. AlHumoud, A. A. Wazrah and W. Aldamegh, "Arabic Chatbots: A Survey," (IJACSA) International Journal of Advanced Computer Science and Applications, vol. Vol. 9, no. No. 8, 2018.

[38] Ch.Sanjana, S.G.Deevena, B.Saritha, M. Sastry, D. V. R. Murthy and M. K. Reddy, "Chatbot Design Techniques in Speech Conversation Systems," JASC: Journal of Applied Science and Computations, vol. Volume VI, no. Issue I, January 2019.

[39] R. DALE, "Industry Watch The return of the chatbots," Natural Language Engineering, vol. Volume 22, no. Issue 5, September 2016.

[40] H. Chung, M. Iorga, J. Voas and S. Lee, "Alexa, Can I Trust You?," NIST : National Institute of Standards and Technology, vol. Volume 9, no. Issue 50, September 2017.

[41] G. López, L. Quesada and L. A. Guerrero, "Alexa vs. Siri vs. Cortana vs. Google Assistant: A Comparison of SpeechBased Natural User Interfaces," Alexa vs. Siri vs. Cortana vs. Google Assistant: A Comparison of Speech-Based Natural User Interfaces, Gusta Advances in Intelligent Systems and Computing, Vols. Alexa vs. Siri vs. Cortana vs. Google Assistant: A Comparison of Speech-Based Natural User Interfaces, Gustavo Ló Volume 592, 2018.

[42] N. MARECHAL, "When Bots Tweet: Toward a Normative Framework for Bots on Social Networking Sites," International Journal of Communication, vol. Volume 10, 2016.

[43] K. Manzoor, What are Chatbots? Beginner's Guide To Chatbots, McKinsey , 2017.

[44] K. Nimavat and P. T. Champaneria, "Chatbots: An overview. Types, Architecture, Tools and Future Possibilities," IJSRD - International Journal for Scientific Research \& Development, vol. Vol. 5, no. Issue 07, 2017.

[45] E. Adamopoulou and L. Moussiades, An Overview of Chatbot Technology, Springer Nature Switzerland AG, 2020.

[46] E. Din, CHATBOTS: THE DEFINITIVE GUIDE, Artificial Solutions, 2020..

[47] S. A. Abdul-Kader and D. J. Woods, "Survey on Chatbot Design Techniques in Speech Conversation Systems," (IJACSA) International Journal of Advanced Computer Science and Applications, vol. Volume 6, no. No. 7, 2015

[48] D. R. S. W. A. L. L. A. C. E, The Elements of AIML Style, ALICE A. I. Foundation Inc Press, 2003.

[49] M. Dahiya, "A Tool of Conversation: Chatbot," International Journal of Computer Sciences and Engineering, Vols. Volume-5, no. Issue-5, 2017.

[50] L. Bradeško and D. Mladenić, "A Survey of Chabot Systems through a Loebner Prize Competition," in Proceedings of Slovenian Language Technologies Society Eighth Conference of Language Technologies, 2012.

[51] Madhumitha.S, Keerthana.B and Mrs.Hemalatha.B, Interactive Chatbot Using AIML, Int. Jnl. Of Advanced Networking \& Applications (IJANA), 2019.

[52] N. Teckchandani, A. Santokhee and G. Bekaroo, AIML and Sequence-to-Sequence Models to Build Artificial Intelligence Chatbots: Insights from a Comparative Analysis, Springer Nature Switzerland, 2019.

[53] S. A. Abdul-Kader and D. J. Woods, Survey on Chatbot Design Techniques in Speech Conversation Systems, International Journal of Advanced Computer Science and Applications, 2015.

[54] H. Yamaguchi, M. Mozgovoy and A. Danielewicz-Betz, A Chatbot Based On AIML Rules Extracted From Twitter Dialogues, Communication Papers of the Federated Conference on Computer Science and Information Systems, 2018.

[55] N. Teckchandani, A. Santokhee and G. Bekaroo, AIML and Sequence-to-Sequence Models to Build Artificial Intelligence Chatbots: Insights from a Comparative Analysis, Springer Nature Switzerland AG 2019.

[56] D. Ireland, H. Hassanzadeh and S. N. Tran, Sentimental Analysis for AIML-Based E-Health Conversational Agents, Springer Nature Switzerland AG 2018, 2018.

[57] M. d. G. B. Marietto, R. V. d. Aguiar, G. d. O. Barbosa, W. T. Botelho, E. Pimentel and R. d. S. França, Artificial Intelligence MArkup Language: A Brief Tutorial, International Journal of Computer Science \& Engineering Survey, 2013.

[58] S. Janarthanam, Hands-On Chatbots and Conversational UI Development : Build chatbots and voice user interfaces with Chatfuel, Dialogflow, Microsoft Bot Framework, Twilio, and Alexa Skills, Birmingham: Packt Publishing Ltd., 2017.

[59] Navin Sabharwal, Sudipta Barua, Neha Anand and Pallavi Aggarwal, Developing Cognitive Bots Using the IBM Watson Engine, Apress Media LLC, 2020 .

[60] A. Singh, K. Ramasubramanian and S. Shivam, Building an Enterprise Chatbot : Work with Protected Enterprise Data Using Open Source Frameworks, Apress Media LLC, 2019.

[61] S. Sannikova, Chatbot implementation with Microsoft Bot Framework, Metropolia University Press, 2017.

[62] D. Braun and FlorianMatthes, "TowardsaFrameworkforClassifyingChatbots," in International Conference on Enterprise Information Systems (ICEIS 2019), 2019.

[63] N. Asher, "A Warmer Welcome : Application of a Chatbot as a Facilitator for New Hires Onboarding," Linnaeus University Press, 2017. 
